
Klasik Sistematik ve ITS Gen Dizileri ile Analizi

\author{
Bekir Çöl ${ }^{1}{ }^{1}$, Ezgin Tırpan ${ }^{1}$, Ebru Balcı ${ }^{1}$, Hakan Allı ${ }^{1}$, Dilek Akkanat ${ }^{1}$, İsmail Şen ${ }^{1}$ \\ ${ }^{1}$ Muğla University, Faculty of Science, Department of Biology, TR 48170 Muğla, Turkey \\ E-mail: bcol@mu.edu.tr
}

Geliş Tarihi: 12.01.2017 ; Kabul Tarihi: 03.08.2017

Özet

\section{Anahtar kelimeler}

Gymnopus ocior,

Gymnopus dryophilus,

ITS,

Barkod Gen.

Morfolojik ve mikroskobik karakterlerinin benzerliği nedeniyle, Gymnopus (Pers.) Gray (Basidiomycota, Omphalotaceae) cinsine ait Gymnopus dryophilus (Bull.) Murrill ve Gymnopus ocior (Pers.) Antonín \& Noordel türlerinin klasik yöntemlerle ayrımı oldukça zordur. Bu yüzden bu çalışmada, Muğla ve Kütahya'dan toplanan bu iki türe ait örneklerin teşhisinde yardımcı olmak üzere, moleküler sistematik yaklaşımdan yararlanılmıştır. Bunun için, makrofunguslarda evrensel barkod geni olan ITS (Internal Transcribed Spacer) bölgesi tercih edilmiştir. Ülkemizden toplanan söz konusu mantar örneklerinin ITS gen dizileri veri tabanlarına kazandırılmış ve biyoinformatik analizler sonucu filogenetik ağaç oluşturulmuştur. Sonuç olarak, G. ocior ve $G$. dryophilus örneklerinin ayrımında ITS gen dizi analizinin, tür teşhisinde destekleyici olabileceği gösterilmiştir.

\title{
ITS gene and Classical Systematic Analyzes of Gymnopus ocior (Pers.) Antonin \& Noordel ve Gymnopus dryophilus (Bull.) Murrill species collected from Muğla and Kütahya
}

\begin{tabular}{|c|c|}
\hline & \\
\hline & $\begin{array}{l}\text { Due to the similarities in morphological and microscopic characters, it is sometimes difficult to } \\
\text { distinguish the species of Gymnopus dryophilus (Bull.) Murrill and Gymnopus ocior (Pers.) Antonín \& }\end{array}$ \\
\hline & Ionging to the genus of Gymnopus (Pers.) Gray (Basidiomycota, Omphalotaceae by using \\
\hline $\begin{array}{l}\text { Gymnopus ocior, } \\
\text { ITnopus dryophilus, } \\
\text { ITS, }\end{array}$ & $\begin{array}{l}\text { only classical approaches. Therefore, in this study, the approach of molecular systematic was utilized in } \\
\text { order to be used as an aid to identifying the two -mentioned- species collected from Muğla and } \\
\text { Kütahya. For this purpose the universal barcode gene for the mancrofungi world ITS (Internal }\end{array}$ \\
\hline Barcode Gene. & $\begin{array}{l}\text { Transcribed Spacer) was preferred. As a result of this study, ITS gene sequences of the macrofungi } \\
\text { samples collected from our country have been added to the gene databases and following some } \\
\text { bioinformatics analyzes, the phylogenetic tree were constructed. In conclusion, we report that ITS gene } \\
\text { sequence analysis can contribute to the identification of G. ocior and G. dryophilus species. }\end{array}$ \\
\hline
\end{tabular}

\section{Giriş}

Gymnopus (Pers.) Gray cinsi dünya genelinde geniş bir yayılış alanına sahip olup, 300 civarında tür içerir (Antonin et al. 2013). Ülkemizde ise bu cinse ait 13 tür bulunmaktadır (Akata and Uzun 2017; Akata 2017; Afyon and Konuk 2002; Baba et al. 2012; Gücin et al. 1995; Işıloğlu et al. 1998; Kaşık et al. 2005; Kaya 2000; Öztürk et al. 2010; Öztürk and Kaşık 1996; Sesli and Denchev 2014; Solak et al.
2015; Pilat 1933; Watling and Gregory 1977). Cinse, yakın zamanda Türkiye' ye endemik olan Gymnopus trabzonensis Vizzini, Antonin, E. Sesli \& Contu türü eklenmiş ve toplam sayı 14'e çıkmıştır (Vizzini et al. 2015).

Çalışma konumuzu oluşturan Gymnopus dryophilus (Bull.) Murrill ve Gymnopus ocior (Pers.) Antonín \& Noordel. türleri makroskobik ve mikroskobik karakterler bakımından birbirine oldukça benzerlik gösterir (Antonin and Noordeloos 2010). Bu 
benzerlikler teşhis aşamasında araştırmacıları yanılgıya düşürebilmektedir. Klasik yöntemlere ek olarak moleküler yaklaşımların da değerlendirilmesi yapılan teşhisin güvenilirliğini arttırmaktadır.

Muğla ve Kütahya'dan toplanan bu iki türe ait örnekler, Muğla Sıtkı Koçman Üniversitesi Kriptogram laboratuvarında makroskobik ve mikroskobik olarak incelenmiş ancak teşhislerinde bazı zorluklarla karşılaşıımıştır. Kesin teşhislerinin sağlanması amacı ile burada $G$. dryophilus ve $G$. ocior türlerine ait örneklerin ITS gen sekanları belirlenerek; gen dizilimlerinin bu iki tür arasında ayırt edici olup, olmadığı araştırılmıştır.

Makrofunguslarla ilgili filogenetik çalışmalarda, çekirdek ve mitokondriyal rDNA bölgeleri (18S rDNA, ITS vb.) ile protein kodlayan genler (RPB1, EF-1 $\alpha$ vb.) kullanılmaktadır (Taşkın, 2011). ITS bölgesi, tür tespiti ve türler arası ilişkilerde özellikle makrofungus taksonomisinde kabul gören resmi bir moleküler barkottur (Schoch et al. 2012). Bu bölge diğer bölgelerden daha değişken olup, daha hızlı evrim geçirdikleri için, aynı cins içindeki türler arasında, tür içi populasyonlar arasındaki çalışmalar için oldukça uygun bölgelerdir (Taşkın, 2011). Tek örneğin dizi analizi, mevcut diziler ile karşılaştırıldığında, anlamlı taksonomik bilgi elde etmek için kullanılabilmektedir.

\section{Materyal ve Metot}

Çalışmada kullanılan örneklerden $D$ 17, D 18, D 22 ve $D 40$ Muğla'nın Kötekli yerleşkesinden ve Allı 3709 ve Allı 3722 örnekleri ise Kütahya'dan 20112014 yılları arasında toplanmıştır. Bulunan bu örneklerin morfolojik ve habitat özellikleri not edilmiş, fotoğrafları çekilmiş ve uygun koşullarda laboratuvar ortamına taşınmıştır. Örnekler, spor baskıları alındıktan sonra kurutulmuş, Muğla Sıtkı Koçman Üniversitesi Fungaryumu' na konmuştur. Her bir örneğin spor rengi, ölçüleri, cystidia ve basidium yapıları mikroskobik olarak fotoğraflanarak incelenmiştir (Leica DM 7500). Makroskobik ve ekolojik özellikleri de dikkate alınarak, literatür bilgileri ışığında tür tespit çalışmaları yapılmıştır (Antonin and Noordeloos 2010; Knudsen and Vesterhold 2012).

\subsection{Genomik DNA izolasyonu ve ITS PCR} 0,05-0,1 gr kuru mantar ile Qiagen Plant Minikit protokolü veya Balcı (2016)'da ki Silika dioksit yöntemi kullanılarak, örneklerden DNA izolasyonları yapılmıştır. DNA'lar $-20^{\circ} \mathrm{C}^{\prime} \mathrm{de}$ saklanmıştır. DNA'yı agaroz jelde görüntülemek için; $4 \mu \mathrm{l}$ DNA, $2 \mu$ yükleme boyası (6X) ve $4 \mu \mathrm{l} 1 \mathrm{X}$ TAE kullanılmıştır. Örnekler, $\% 0,8^{\prime}$ lik agaroz jelde yürütülmüş ve UV ışık altında görüntüleme yapılmıştır (DNRminiBisPro).

Genomik DNA izolasyonu yapılan mantar türlerinin moleküler yöntem ile tanımlanabilmesi için mantarlar için barkod geni olan ITS (Internal Transcribed Spacer) bölgesi kullanılmıştır. ITS1 (3'TCC GTA GGT GAA CCT GCG G -5') veya ITS1F (3'CTT GGT CAT TTA GAG GAA GTA A $-5^{\prime}$ ) ve ITS4 (5'TCC TCC GCT TAT TGA TAT GC - $3^{\prime}$ ) primerleri kullanılarak, ITS-PCR yapılmıştır. Örnek miktarının bir fazlası oranında sırasıyla; $31,5 \mu \mathrm{ldH} 2 \mathrm{O}, 5 \mu \mathrm{l}$ 10X Taq Buffer, $4 \mu \mathrm{l} \mathrm{MgCl} 2(10 \mathrm{mM}), 5 \mu \mathrm{dNTP}(2 \mathrm{mM})$,

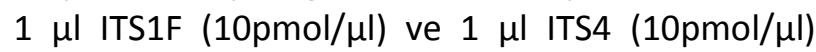
karışıma eklenerek PCR karışımı hazırlanmış, etiketlenen PCR tüplerine genomik DNA'dan 2'şer $\mu$ l eklenmiştir. Son olarak PCR karışımına 0,5 $\mu \mathrm{l} \mathrm{Taq}$ Polimeraz enzimi $(5 \mathrm{U} / \mu \mathrm{l})$ eklenmiş, karışım iyice pipetlenerek son hacim $50 \mu$ l olacak şekilde PCR tüplerine ilave edilmiş, DNA örneği ile iyice karışması sağlanmıştır.

PCR programı olarak; örnekler 35 döngü olacak şekilde; $94^{\circ} \mathrm{C}^{\prime}$ de 3 dakika (ilk denatürasyon), $94^{\circ} \mathrm{C}^{\prime}$ de 1 dakika (denatürasyon), $52^{\circ} \mathrm{C}^{\prime}$ de 1 dakika (bağlanma), $72^{\circ} \mathrm{C}^{\prime}$ de 2 dakika (uzama) ve takiben $72^{\circ} \mathrm{C}^{\prime}$ de 10 dakika (son uzama)'da tutulmuştur. Daha sonra PCR ürünleri \%0,8'lik agaroz jele $8^{\prime}$ er $\mu \mathrm{l}$ yüklenmiş, 100 V'da elektroforez yapılmıştır. Sonucunda UV ışık altında görüntüleme yapılmıştır (DNRminiBisPro).

\subsection{Pürifikasyon, sekanslama ve biyoinformatik analizler}

PCR ürünlerinin miktarı arttırılmış, daha sonra 1,5 ml'lik ependorfta aynı örnekler birleştirilmiştir.

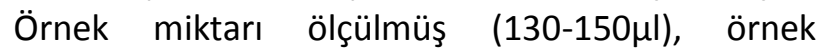
miktarının 1:4'ü oranında 6X Dye yükleme boyası (loading dye) eklenmiş ve \% 0,8 oranında agaroz jel hazırlanarak, boya ile iyice karıştırılan örnekler jele yüklenmiştir. Örneklerin jelin sonuna kadar yürümesi sağlanarak istenmeyen her türlü banttan temizlenmesi sağlanmış, ITS bandları UV ışık altında kesilerek alınmıştır. Kesilen örneklere ait jellerin miktarları tartılmıştır. Daha sonra Fermentas GeneJET Gel Extraction Kit'i kullanılarak PCR ürünleri saflaştırılmıştır. Elde edilen DNA'lar 
tekrardan \%0,8'lik agaroz jele $1 \mu$ yüklenmiş ve UV ışık altında görüntülenmiştir (DNRminiBisPro).

DNA'nın nükleotid dizisini saptamak amacı ile 30-50 $\mu l$ PCR ürünü saf DNA, ITS1 ya da ITS1F ve ITS4 primerleri ile çift okuma sekans analizi yapılmıştır (Macrogen, Hollanda). ITS1F ve ITS4 primerleri ile okutulan sekanslar, Bioedit programında birleştirilerek, kontig sekans oluşturulmuştur (Int Kyn. 1). Örneğin kontig sekansı NCBI BlastN programında bulunan diğer Genbank nükleotid verileri ile karşılaştırılmıştır. Filogenetik analiz için ITS sekansı Clustal W kullanılarak hizalanmıştır. Filogenetik ağaç Neighbour-Joining metodu kullanılarak, Mega 6'da oluşturulmuştur (Tamura et al. 2013). Elde edilen filogenetik ağacın geçerliliği ve dalların güvenilirliği açısından Bootstrap analizi 10.000 kez tekrarlanmıştır.

\section{Bulgular}

Gymnopus dryophilus ve Gymnopus ocior türlerine ait Kütahya ve Muğla illerinden toplanan örneklerin, filogenetik ve klasik sistematik yöntemler yardımıyla tür teşhisleri sağlanmıştır.

\subsection{Fenotipik ve mikroskobik bulgular}

\section{Gymnopus dryophilus (Bull.) Murrill}

Şapka, 10-60 mm, konveksten düze değişen şekillerde, turuncu kahve veya okra kahve tonlarda, kenarları belirgin şekilde çizgili ve ıslanınca saydamlaşan yapıdadır (Şekil 1a, 1b,1c,1d). Lameller beyaz-soluk krem, sık yapıda, adnat-emerginat. Sap $30-120 \times 1-5 \mathrm{~mm}$., pürüzsüz, şapkayla aynı veya daha soluk renktedir (Şekil 1b, 1c). Sporlar, $4-7 \times 2,5-4 \mu \mathrm{m}$, şeffaf, elips şeklinde (Şekil 1e). Sistidia $15-70 \times 4-12$ $\mu \mathrm{m}$ küçük dallanmalar görülür (Şekil $5 a$ ). Habitat: Humuslu asidik topraklarda, ormanlık alanlarda bitki döküntülerinin arasında grup halinde yetişmektedir (Antonin and Noordeloos 2010; Knudsen and Vesterhold 2012).

Değerlendirilen örnekler: Kötekli-Yeniköy arası Pinus brutia Ten. ormanı, 15.04.2013, D 22, D 40.

Alikahya Köyü, Gediz, Pinus brutia Ten., Quercus sp. karışık ormanı, 630 m., 21.10.2011, Allı 3709, 3722.

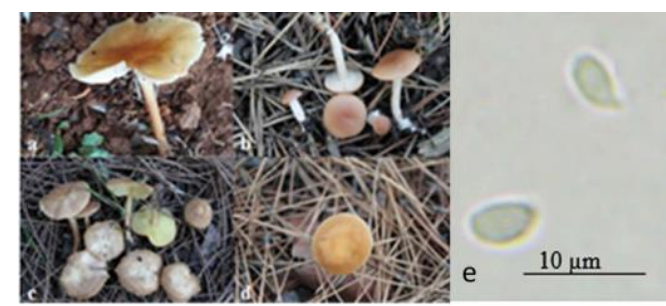

Şekil 1. Gymnopus dryophilus, a. Bazidiyokarp D 22, b. Bazidiyokarp D 40, c. Bazidiyokarp Allı 3722, d., Bazidiyokarp Allı 3709, e. Bazidiyospor.

\section{Gymnopus ocior (Pers.) Antonín \& Noordel.}

Şapka, 10 - $40 \mathrm{~mm}$, konveks, koyu kırmızımsı kahve, kenarları soluk renkte, kenarları ıslanınca saydamlaşan yapıdadır (Şekil 2a) . Lameller beyaz, krem veya sarı, sık yapıda, adnat-emerginat. Sap 20 - $60 \times 2-5$ mm., silindirik, pürüzsüz, sarı veya okra renktedir (Şekil 2b). Sporlar, 4,5-6 2,5-4 $\mathrm{m}$, şeffaf, elips şeklinde (Şekil 2c). Sistidia $12-45 \times 3-$ $9 \mu \mathrm{m}$ düzensiz ve geniş, loblu dallanmalar görülür (Şekil 5b). Habitat: Humuslu topraklarda, yaprak döken ağaçların olduğu ormanlık alanlarda odun kırıntıları arasında genellikle grup halinde yetişmektedir (Antonin and Noordeloos 2010; Knudsen and Vesterhold 2012).

Değerlendirilen örnekler: Kötekli-Yeniköy arası Pinus brutia Ten. ormanı, 15.04.2013, D 17, D 18.

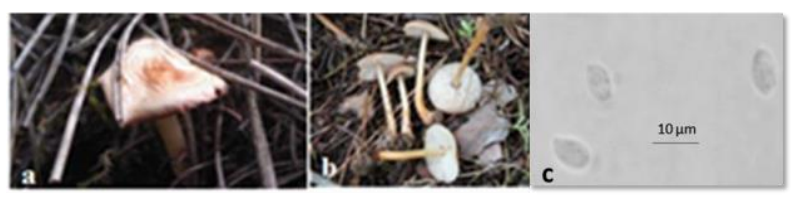

Şekil 2. Gymnopus ocior, a. Bazidiyokarp D 17, b. Bazidiyokarp D 18, c. Bazidiyospor.

\subsection{Moleküler çalışmalar sonucu elde edilen bulgular}

Kuru makrofungus örneklerinden genomik DNA izolasyonu yapılmış, iki türe ait örneklerin ITS gen bölgesi çoğaltılmıştır. Çoğaltılan DNA'nın pürifikasyonu yapılmıștır. Agaroz jel elektroforez görüntüleri elde edilmiştir (Şekil 3). 


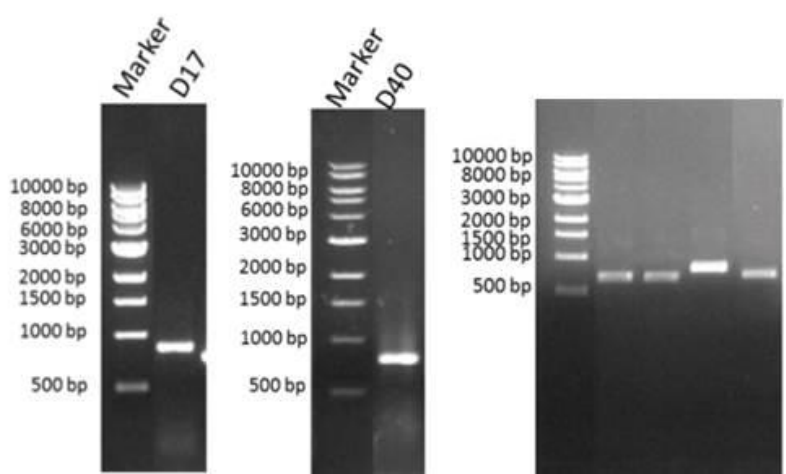

Şekil 3. $D 17$ ve $D 40$ no'lu örneklere ait ITS PCR ve pürifikasyon agaroz jel elektroforez görüntüleri
QV20 değerleri göz önünde bulundurularak Bioedit programı ile kontig işlemi yapılmış ve BlastN analizi sonucu Mega6 programı ile türlere ait filogenetik ağaçlar oluşturularak örneklerin moleküler olarak tanımlamaları yapılmıştır (Şekil 4).

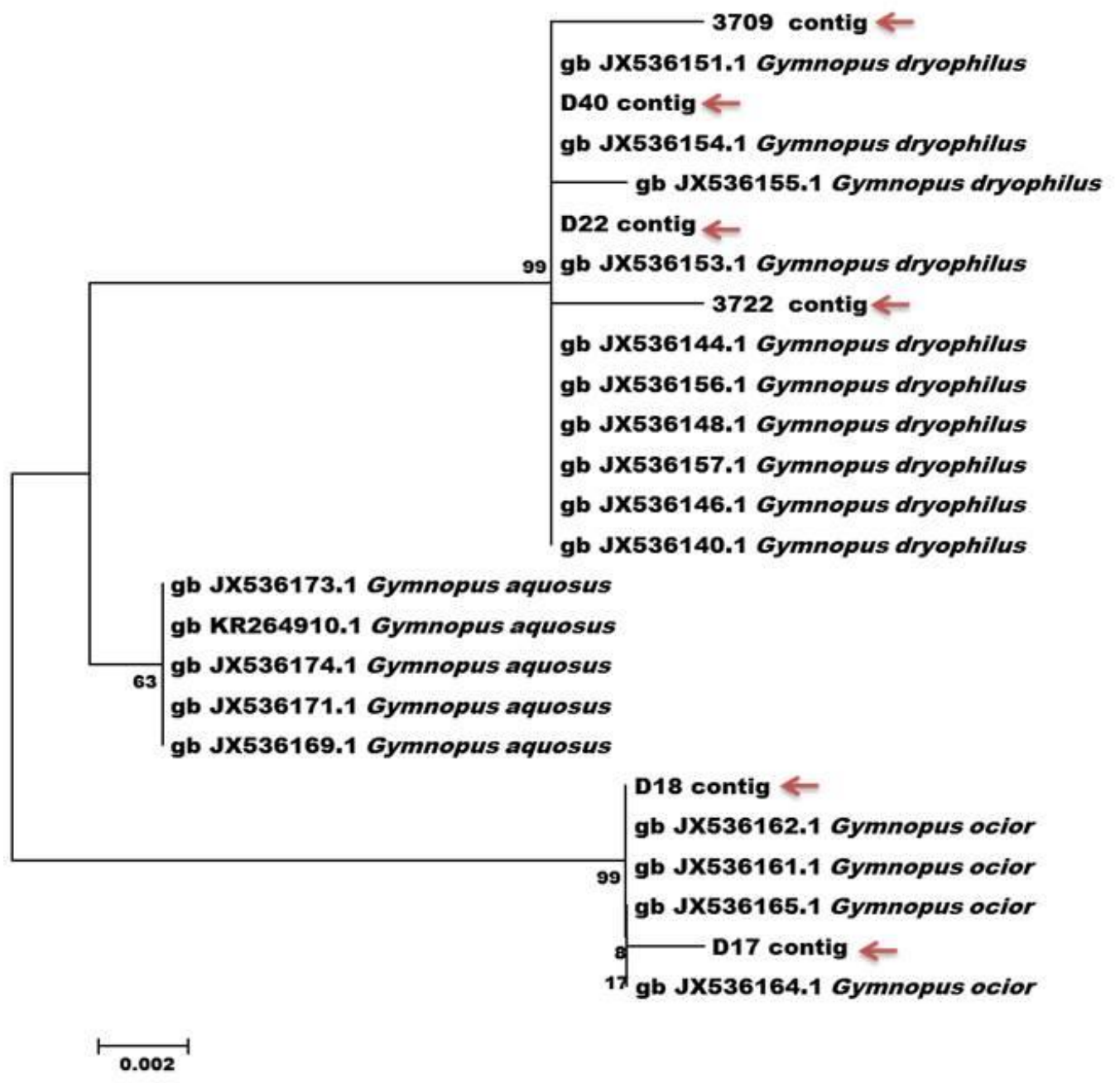

Şekil 4. Örneklere ait filogenetik ağaç

\section{Tartışma ve Sonuç}

Bu çalışmada, Muğla ve Kütahya'dan toplanan ve teşhislerinde zorlanılan Gymnopus ocior'a ait 6 örneğin morfolojik ve moleküler yöntemler kullanılarak tür tayinleri yapılmıştır.
Gymnopus cinsi Levipedes bölümü, $8 \mathrm{~cm}$ ve altı büyüklükte, gençken konveks ve kenarları içe doğru kıvrık yaşlandıkça düzleşen yapıda, tüysüz ve kaygan yapıda, krem ve kahve tonlarda şapkaya, beyaz, sık ve sapa bağlı lamellere (adnate- 
emerginate), elips şeklinde renksiz, inamiloid sporlara sahiptir. Çoğunlukla kümelenmiş olarak yaşayan, saprofitik özellikte olan bu grup, sekiz takson (G. alpinus (Vilgalys \& O.K. Mill.) Antonín \& Noordel., G. aquosus (Bull.) Antonín \& Noordel., G. dryophilus (Bull.) Murrill, G. erythropus (Pers.) Antonín, Halling \& Noordel., G. fagiphilus (Velen.) Antonín, Halling \& Noordel., G. hybridus (Kühner \& Romagn.) Antonín \& Noordel., G. lanipes (Malençon \& Bertault) Vila \& Llimona ve $G$. ocior (Pers.) Antonín \& Noordel.) içermektedir (Antonin et al. 2013). Özellikle, bu bölüm içinde yer alan $G$. ocior ve $G$. dryophilus morfolojik olarak benzer karakterlere sahip olması nedeniyle birçok araştırmacı tarafından karıştırılmaktadır. Antonin ve ark. (2013)'e göre bu taksonlar G. dryophilus grubu olarak isimlendirilmektedir. Sunulan bu çalışma kapsamında, Muğla ve Kütahya yörelerinden toplanan $G$. ocior ve $G$. dryophilus örnekleri morfolojik ve moleküler olarak analiz edilmiş ve tartışılmıştır.

G. ocior, G. dryophilus'a göre daha koyu ve kırmızımsı renkte şapkaya sahiptir. Ayrıca $G$. dryophilus'un şapka kenarı çizgili yapıdadır. Bir diğer fark ise, G. ocior 'un lamelleri beyaz veya limon sarı olabilirken $G$. dryophilus'un lamelleri beyaz veya krem tonlardadır (Antonin and Noordeloos 2010; Knudsen and Vesterhold 2012). Bulunan örneğin yaşlı veya kurumuş olması durumunda renk değişikliğinden dolayı bu iki türü ayırt etmek zorlaşmaktadır (Şekil 1c, 2a). Mikroskobik özelliklerine bakıldığında da spor boyut ve şekilleri birbirlerine yakındır (Şekil 1e, 2c). Bunun yanı sıra cheilocystidia yapıları iki türde de clavate veya coralloid yapıdadır. Ancak, G. ocior' da daha geniş, loblu dallanma görülmektedir (Şekil 5) (Knudsen and Vesterhold 2012; Antonin et al. 2013).

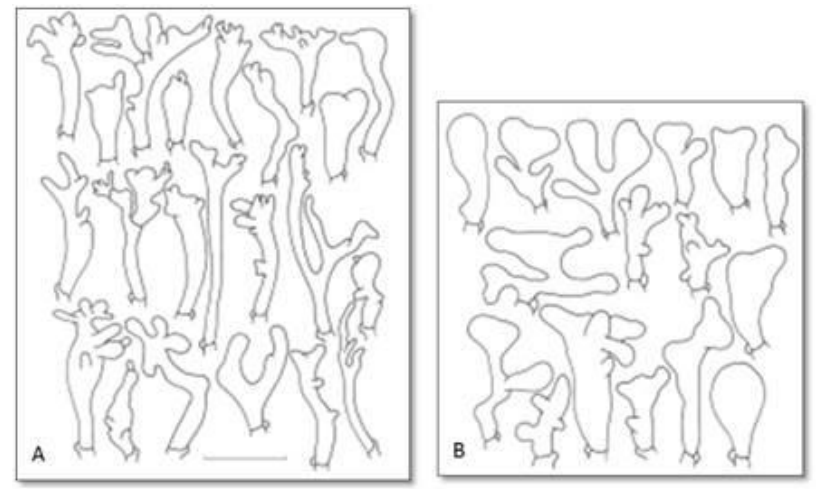

Şekil 5. Örneklere ait cheilocystidia yapıları a. G. dryophilus, b. G. ocior (Antonin et al. 2013).
İki tür arasında makroskobik ve mikroskobik karakterler bakımından büyük benzerlikler bulunması ve değerlendirilen örneklerin morfolojik karakterlerinin özellikle kuru örneklerde ayırması çok zor olduğu için, yapılan teşhisleri desteklemesi amacıyla moleküler sistematik yöntemlere başvurulmuştur.

ITS gen dizilerinin BlastN analizi sonucu değerlendirilerek oluşturulan filogenetik ağaçta örneklerin teşhisi sağlanmış ve bu iki tür arasındaki ayrım net olarak ortaya konmuştur (Şekil 4). Ayrıca örneklerin birbirlerine benzerliklerini saptamak için align two analizi yapılmış, Alı 3709, Alı 3722, D 22, $D 40$ örnekleri ile $G$. dryophilus türü ve $D 17, D 18$ örnekleri ile $G$. ocior türü kendi aralarında \%97 ve üzerinde benzerlik gösterirken bu oran farklı türler arasında \%97'nin altındadır. Bu sonuçlar, filogenetik ağaç verilerini destekler niteliktedir.

Muğla ve Kütahya illerinden toplanan $G$. dryophilus ve $G$. ocior türlerine ait altı örnekte olduğu gibi birbirine yakın türleri ayırt etmede ve sistematik açıdan daha güvenilir bilgiler sunmakta moleküler yöntemler oldukça elverişlidir. Bu çalışmada da görüldüğü üzere, ITS (Internal Transcribed Spacer) barkod geni kullanılarak elde edilen filogenetik ağaçlar çoğu zaman tür teşhisi konusunda klasik sistematiğe ışık tutmakta olup, gerekli görüldüğü takdirde kullanılması önerilmektedir.

\section{Teşekkür}

Bu çalışma TÜBITAK tarafından $110 R 019$ no' lu proje kapsamında desteklenmiştir. TÜBITAK'a teşekkür ederiz.

\section{Kaynaklar}

Akata, I. and Uzun, Y., 2017. Macrofungi determined in Uzungöl Nature Park (Trabzon). Trakya Unıversity Journal of Natural Sciences 18(1): xx-xx, DOI: 10.23902/trkjnat.295542.

Akata, I. 2017. Macrofungal Diversity of Belgrad Forest (İstanbul). Kastamonu Üniversitesi Orman Fakültesi Dergisi 17 (1): 150-164.

Afyon, A. and Konuk, M., 2002. A study on macrofungi of Zonguldak District. The Herb Journal of Systematic Botany 9(1): 121-128. 
Antonin, V. and Noordeloos, M.E., 2010. A monograph of marasmioid and collybioid fungi in Europe. IHWVerlag.

Antonín, V., Sedlák, P. and Tomšovský, M., 2013. Taxonomy and phylogeny of European Gymnopus subsection Levipedes (Basidiomycota, Omphalotaceae). Persoonia 31: 179-187.

Baba H., Alkan S., Kaşık G., 2012. Hatay Kent Merkezi (Antakya) ve Habib-i Neccar Dağında Yayılış Gösteren Makromantar Çeşitliliği, 21. Ulusal Biyoloji Kong., 3-7 Eylül 2012, p. 1180, Bornova-izMiR.

Balcı E., 2016. Bazı Stereum hirsutum ve Schizophyllum commune Makrofungus Türlerine ait Örneklerden Misel Üretimi ve RAPD-PCR Analizi ile Genetik Akrabalıklarının Araştırılması. Yüksek lisans tezi, Muğla Sıtkı Koçman Üniversitesi Fen Bilimleri Enstitüsü, Muğla, 65.

Gücin, F., Işıloğlu, M., Solak, M.H. 1995. Macrofungi of Kozak plateau (West Anatolia). XIlth Congress of European Mycologists, Wageningen, 3-7 September. P. 22. Wageningen, The Netherlands. pp: 27.

Işıloğlu, M., Solak, M.H., Gücin, F. 1998. The edible macrofungi of northwest Anatolia. 5th International Symposium Plant Life in South-West and Central Asia, Tashkent, 18-22 May 1998. Pp. 88-90. Tashkent.

Kaya, A. 2000. New records of Tricholomataceae for the mycoflora of Turkey. Bulletin of Pure and Applied Sciences 19B(2): 77-81.

Kaşık, G., Doğan, H.H., Öztürk, C., Aktaş, S., Sabahlar, Ş. 2005. New records of the macrofungi from Turkey. Pakistan Journal of Botany 37 (3): 769-777.

Knudsen, H. and Vesterhold, J., 2012. Funga Nordica. Copanhagen: Nordsvamp.

Öztürk, C., Kaşık, G. 1996. Macrofungi in Ürgüp District. Selçuk Üniversitesi Fen Edebiyat Fakültesi Fen Dergisi 13: 50-54.

Öztürk Ö., Doğan, H.H., Yıldırımlı, Ş. 2010. Macrofungi of Eldivan dağ. (Çankırı), Ot sistematik Botanik Dergisi, 17 (2): 141-154.
Pilát, A.A. 1933. Additamenta ad floram Asiae Minoris hymenomycetum pars secunda: Agaricineae. Bulletin Trimestriel Society Mycologie France 49: 283-302.

Schoch, C.A., Seifert, K.A., Huhndorf, S., Robert, V., Spouge, J.L., Levesque, C.A., Chen, W. and Fungal Barcoding Consortium, 2012. Nuclear ribosomal internel transcribed spacer (ITS) region as a universal DNA barcode marker for fungi, Proceedings of the National Academy of Sciences of the United States of America, 109 (16): 6241-6246.

Sesli, E., Denchev, C.M. 2014. Checklists of the myxomycetes, larger ascomycetes, and larger basidiomycetes in Turkey. 6th edn. Mycotaxon Checklists Online (http://www.mycotaxon.com/resources/checklists/s esli-v106-checklist.pdf): 1-136.

Solak, M.H., Işıloğlu, M., Kalmış, E. and Allı, H., 2015. Macrofungi of Turkey, Checklist Vol. 2. İzmir Üniversiteliler Ofset.

Taşkın, H. 2011. Türkiye florasında yetişen kuzugöbeği mantarlarının moleküler karakterizasyonu. Yüksek Lisans Tezi, Çukurova Üniversitesi Fen Bilimleri Enstitüsü, Adana, 167.

Tamura, K., Stecher, G., Peterson, D., Filipski A.,3 and Kumar S., 2013. MEGA6: Molecular Evolutionary Genetics Analysis Version 6.0, Oxford University, Molecular Biology and Evolution, 30(12):2725-2729.

Vizzini, A., Antonin, V., Sesli, E. and Contu, M., 2015. Gymnopus trabzonensis sp. nov. (Omphalotaceae) and Tricholoma virgatum var. fulvoumbonatum var. nov. (Tricholomataceae), two new white-spored agarics from Turkey. Phytotaxa. 226(2):119-130.

Watling, R. and Gregory, N.M. 1977. Larger fungi from Turkey, Iran and neighbouring countries. Karstenia 17: $59-72$.

Webster, J. and Weber, R.W.S., 2007. Introduction to Fungi, 3, Cambridge University Press, Newyork.

\section{internet kaynakları}

1-http://www.mbio.ncsu.edu/bioedit/bioedit.html, (05.01.2017) 